\title{
Crisis of What?
}

\author{
Leo Panitch \\ York University \\ $\underline{\text { lpanitch } a \text { yorku.ca }}$
}

This sharp question is appropriately thought-provoking. We certainly have been living through a great capitalist crisis, really only the fourth crisis of such scale after the so-called Great Depression of 1873-96, the more familiar Great Depression of the 1930s, and the global stagflation and profitability crisis of the $1970 \mathrm{~s}$. The very fact that capitalism survived these earlier crises should warn us away from reverting to the old mistaken notions of economic crises heralding the final breakdown of the system. But could this at least be a major turning point? Is this at least a crisis of neoliberalism? Or of American empire? Or even perhaps of "globalization"?

Previous great crises certainly marked historic turning points. The first fueled the emergence of a new type of inter-imperial rivalry which culminated in a world war. The second led to another, after having already written finis to the British gold standard/empire of free trade. This already should have taught a lesson to those who imagined that globalization is no more than an inevitable outcome of capitalism's structural tendencies to expansion. Those tendencies were powerful, but the actual spread of capitalism up to World War II was not the automatic result of the operation of any historical "law." It was, rather, the product of human agents and the institutions they created, and its interruption by the 1930 s reflected the way the new contradictions and conflicts this had fostered interacted with older barriers to capitalism's global expansion.

As Sam Gindin and I have shown in The Making of Global Capitalism, the way capitalism's globalizing tendencies were revived after 1945 through the postwar 'golden age' cannot be understood apart from the active role of the United States in penetrating and restructuring other states - above all the other great capitalist states of Europe and Japan - and incorporating them under the aegis of the new informal American empire (Panitch and Gindin 2012). And the 1970s demonstrated that capitalist crises, despite the wishful thinking of Keynesians and social democrats, were by no means a thing of the past. Yet despite the breakdown of the Bretton Woods system of fixed exchange rates, which as many mainstream as radical analysts believed signaled both the loss of U.S. economic and political hegemony and the re-emergence of inter-capitalist state rivalry, what in fact happened - in contrast to the 1930s was greater interstate cooperation; this occurred within an expanded institutional framework of informal American empire, to promote the acceleration of capitalist globalization rather than retreat from it. The increasing interpenetration of MNCs among the advanced capitalist states, alongside greater capital flows and trade, was facilitated by expanded linkages among their finance ministries and central banks, with the U.S. Treasury and Federal Reserve remaining very much both the pinnacle and hub of their interaction. This remained the case even as - and after the EU, on the one hand, and the G7 on the other, were constructed. 
The crisis of the 1970s was managed with the aid of the development of derivative markets in the United States that smoothed the transition to floating exchange rates, but it was not until the underlying cause of the inflationary and profitability crisis which beset all advanced capitalist states was addressed that the crisis was brought to an end. This involved breaking the working class militancy that had developed ever since near full employment had been reached in the 1960s. This was a long, drawn out process that moved at different paces within each advanced capitalist country, but it was only sealed with the Federal Reserve's Volcker Shock that straddled the Carter and Reagan administrations. The use of high interest rates to induce austerity and unemployment to a degree that would break the back of trade unionism finally secured the inflation-proof stability of the dollar. This cleared the way for the neoliberal policies that fostered both class inequality and class discipline. In social terms, this is above all what the vast expansion of global financial markets and production networks fundamentally represented.

Finance, already nurtured back to health through the postwar decades, was now sustained in its vast growth by floating exchange rates, the complete removal of capital controls, the development of derivative markets, and the increasing integration of working classes into financial and credit markets through pension plans and consumer debt amid stagnant real wages. And while the great expansion of finance certainly involved extensive leveraging and speculation, it met the hedging needs not only of financial institutions, but also of the many industrial corporations seeking protection from the rapidly evolving vulnerabilities associated with global trade and investment. But it was a mistake to see the restructuring of the U.S. economy that followed in terms of the "hollowing out" of the material base of the informal American empire. While some industries and regions declined, others opened up amidst the recovery of profits and productivity and the dynamic expansion of communications, bio-medical, and other industries.

The "third world" debt crisis of the 1980s was largely a side effect of the U.S. Federal Reserve's use of high interest rates to break domestic inflationary pressures, but it provided the means to discipline states in the global South along the lines of the "Washington Consensus." This soon included disciplining the formerly Communist regimes into also becoming "emerging market states." Opening up these states to free trade, the free flow of capital, and international treaties that guaranteed the legal treatment of foreign capital on the same terms as national capital, was not undertaken against the dominant local capitalist forces but very much in concert with them. Indeed, it is wrong to see structural adjustment programs as merely imposed from outside. The ruling elites had increasingly wanted neoliberal-style "reforms" in the face of growing contradictions of both import substitution industrialization strategies and actually existing socialism, but given the local balance of social forces, they couldn't secure them without the help of the IMF or World Bank.

The attractions Wall Street held for capitalists abroad reflected the lack of such diversified and deep financial markets in their own countries. It was precisely this lack that made them so vulnerable to financial crisis as they opened themselves to neoliberal globalization. Amidst the 72 financial crises of the $1990 \mathrm{~s}$ in low- and middle-income countries, the U.S. Treasury, as the core state institution around which the International Financial Institutions and the G7 revolved, became "firefighter-in-chief" as it sought to guard against the international reverberation of local financial crises leading to a global financial conflagration. It played the same role in relation to U.S. domestic financial markets, as was seen in the growing coordination of Treasury and Federal Reserve with other domestic regulatory agencies after the 1987 stock market crash. What was clearly involved here was the state walking the tightrope of allowing 
volatile financial markets to flourish, while managing and containing the inevitable crises that such markets spawned. As explained in the most important report on the subject up to the 1990s (prophetically called American Finance for the $21^{\text {st }}$ Century), the Treasury believed that giving regulatory priority to "failure prevention" could only mean tying the hands of financial institutions, "at considerable cost to the economy as a whole and potentially to America's world leadership in financial services." What was needed instead was supervision of a kind that supported the financial sector's "mercurial growth" - and precisely because it was recognized that this would inevitably give rise to financial crises, the main goal of financial policy should be "failure containment."

The practice of "failure containment" was often harrowing for its practitioners, who could never be sure it would work. But it did, even as the 1997 Asian crisis spread to Russia and Brazil, and then to Wall Street itself a year later. There were many who now predicted that it would all come to grief in a new dollar crisis, especially amidst growing U.S. trade deficits after the United States finally allowed China's entry into the WTO. But China's holding its trade surpluses, very much like Japan, in the form of Treasury bonds and other U.S. debt instruments was in fact a measure of its dependence on U.S. consumer markets to sustain its rapid integration into global capitalism, which in turn depended on sustaining the stability of the dollar. Moreover, those who read the trade deficit as indicating the loss of the material base of the U.S. empire ignored the fact that the U.S. exports had grown faster than other G7 countries since the early 1980 s, even if its imports had grown even faster. More fundamentally, they failed to register the significance of the predominance of U.S. MNCs in integrated global production sales and profits, as well as the deep structural reasons for the flow of foreign capital as well as goods into the United States - all of which wreaked havoc with the old types of conclusions based on balance of payments statistics, as least as far as the United States itself was concerned.

The first great economic crisis of the twenty-first century had its roots not in a crisis of the dollar nor in a new accumulation and profitability crisis in U.S. industry, but rather in the derivative market for U.S. mortgage debt which so many foreign as well as domestic investors had accumulated. This crisis had its roots in the volatility of finance, in which both industrial corporations and working classes were themselves now well integrated. The crisis was triggered in the seemingly mundane sector of mortgage credit, where finance mediated working class access to housing, and then quickly spread into the more rarefied world of interbank lending and corporate commercial paper markets. It was because U.S. finance had become so integral to the functioning of $21^{\text {st }}$-century global capitalism that the ultimate impact of this crisis throughout the international economy was so profound, and it proved by far the most challenging to the new imperial practice of "failure containment." To ensure that the "sense of commitment and common purpose" among their finance ministries and central banks was sustained in face of the crisis, the leaders of the G20 states were summoned to Washington for their first ever meeting in the last months of the Bush administration. The communique they issued announced their "Commitment to an Open Global Economy" and underscored "the critical importance of rejecting protectionism and not turning inward," as had happened after the 1929 crash. A main international goal of the Treasury throughout the Obama administration has involved renewing this commitment, at which it has largely succeeded.

It was not the newly developing capitalist states nearly as much as the incapacity of those in Europe to effectively cope with the eurozone crisis that has been seen as posing the greatest danger to global capitalism. The Fed's role as the world central bank was evident in its acting as lender of last resort in 2007-2008 not only for U.S. banks but for foreign banks, from the Bank of 
China, Ltd. to Deutschebank. The Fed's provision of liquidity to U.S. financial institutions themselves has been undertaken with one eye to their passing that liquidity to Europe through the interbank market. The Treasury was intimately involved in European policy discussions, directly as well as through the IMF, with Geithner himself constantly on the phone and even flying over to meet with European finance ministers. It has been the German state which has been most reluctant to take sufficient responsibility for failure containment, while remaining, like all the G7 states, steadfastly committed to sustaining the process of neoliberal globalization.

To be sure, leading capitalists and officials in the United States and elsewhere have been concerned by how the conflict between Congress and the Obama administration would affect the global crisis. This conflict reflects the internal contradiction which the American state faces between acting as both the state of the United States, and as the "indispensable" state of global capitalism. But what is indeed remarkable about the deep partisan gridlock in Washington that has characterized the Obama presidency is that it has not undermined the Treasury's and Fed's practice of failure containment. Moreover, although it was precisely on the grounds of the conflict with Congress that the credit rating agency Standard \& Poor's downgraded U.S. Treasury bonds, what was especially remarkable was that the appetite for these bonds, even at record low interest rates, increased. Ruminations about an alternative reserve currency went nowhere, especially as the smouldering crisis in Europe's interbank markets burst into flames, sending the widespread earlier expectations that the Euro would challenge the dollar up in smoke.

So a crisis of what? Like the 1970 s - and even more notably since it now extends to the developing capitalist states of the G20 - it has not interrupted capitalist globalization. Nor, it must be said, has it ended the era of neoliberalism. Indeed, after the U.S.-coordinated global fiscal stimulus of 2009 , the continuing crisis has seen the reinforcement of neoliberalism. Reviving capitalist health today requires reassuring the bankers and investors whom the states have rescued that their activities will still be appreciated and their assets protected. The unresolved dilemma for all capitalist states today is how to both stimulate the economy and regulate financial markets so as to limit increasingly dangerous volatility without undermining the ability of finance to play its essential role in capitalism. But the old orthodoxy of insisting on austerity - both to ensure that states pay their bond holders and to maintain vigilance against inflation - reinforces the stagnationist tendencies of under-consumption that come with diminished consumer credit and effective demand. For most states, any attempt at fiscal stimulus aggravates the fears of bond holders that they won't be repaid. Moreover, the increased rate of interest on the bonds necessary to fund fiscal and trade deficits requires restructuring state expenditure to prioritize interest payments over social expenditures, infrastructure development, and public employment - thereby negating the very attempt at stimulus. This is the less the case for the United States due to the "safe haven" Treasury bonds represent, the appreciation of which is inseparable from the role of the U.S. state as the ultimate guarantor of global capitalist interests.

The first great economic crisis of the $21^{\text {st }}$ century indeed deserves to be placed alongside the three previous great crises of capitalism. The reasons for this may be measured by the stubbornly high rates of unemployment in most of the advanced capitalist countries (with Germany's lower rate hardly offsetting the mass unemployment on Europe's southern periphery). As for the developing capitalist states, not only did initial expectations that they could use the crisis to "decouple" from globalization prove wrong, the continuing impact of the crisis is now being measured by a notable decline in their own rates of growth. Yet this crisis has 
not produced conflict between capitalist states, as would have been expected by the old theories of capitalist imperialism rather than conflicts within states. Indeed, the greatest danger for global capitalism today is that states that had sworn off capital controls forever may be forced by domestic class struggles into adopting them.

So far only the rise of Syriza in Greece possibly foretells this. Yet to defy the logic of capitalist financial markets and break with the politics of austerity by defaulting on public debt and adopting capital controls is a daunting prospect for any state. In some senses, we are indeed back in 1917. I do not at all mean this in the sense that Lenin did when he argued that interimperial rivalry represented the last stage of capitalism. I mean it rather in the sense that a break in one of the weaker links in the global capitalist chain might this time actually spark a progressive enough shift in the balance of forces in one or more of the major capitalist states as to give some breathing room for a genuinely democratic radical changes in smaller state like Greece. This could only come to pass if renewed popular revolts against neoliberal globalization in the larger states (such as Occupy Frankfurt) could sustain political organizations capable changing the structures and policies of their own capitalists states. Without this the politics of protest will continue to be loud but ineffective, and remain incapable of effectively building the international solidarity needed to turn this crisis into a political crisis for those states which are above all committed to keeping capitalist globalization going.

\section{References}

Panitch, Leo and Sam Gindin. 2012. The Making of Global Capitalism: The Political Economy of American Empire. London: Verso. 